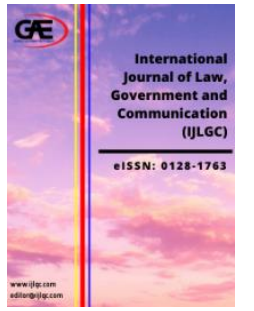

\author{
INTERNATIONAL JOURNAL OF LAW, \\ GOVERNMENT AND COMMUNICATION \\ (IJLGC) \\ www.ijlgc.com
}

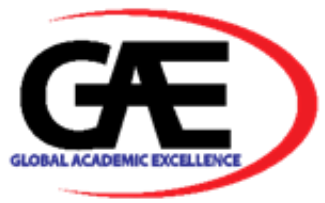

\title{
LEGAL RIGHTS OF INTERNATIONAL WATER RESOURCES: A CASE OF TIGRIS AND EUPHRATES RIVERS
}

\author{
Omar Ahmed Hussein ${ }^{1}$, Khadijah Mohamed ${ }^{2 *}$ \\ 1 College of Law and Political Science, Diyala University, Iraq \\ Email: Dr.omer.ahmed@law.uodiyala.edu.iq; ani3mar@yahoo.com ; Omarlaw78@gmail.com \\ 2 School of Law, College of Law, Government and International Studies, Universiti Utara Malaysia, 06010 Sintok, \\ Kedah Darul Aman, Malaysia \\ Email: khadijah@uum.edu.my \\ * Corresponding Author
}

\section{Article Info:}

Article history:

Received date: 09.11.2020

Revised date: 15.11 .2020

Accepted date: 10.12 .2020

Published date: 10.03.2021

\section{To cite this document:}

Hussein, O. A., \& Mohamed, K. (2021). Legal Rights of International Water Resources: A Case of Tigris and Euphrates Rivers. International Journal of Law, Government and Communication, 6 (22), 130-137.

DOI: $10.35631 /$ IJLGC.6220012.

This work is licensed under $\mathrm{CC}$ BY 4.0

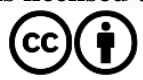

\begin{abstract}
:
This paper aims to examine Iraq's rights, being the downstream country, towards the use of Tigris and Euphrates Rivers and the extent to which international water resources are protected under international law. Being the downstream country, projects constructed on the banks of Tigris and Euphrates Rivers had significantly impacted Iraq as less water flows into the country. The discussion in this paper outlines principles of the existing international conventions and protocols in this area by adopting a doctrinal legal research approach which has great significance to understand the relevant substantive law through the analysis of legal rules, court judgments, and statutes. The paper concludes that historically, Iraq had an acquired right, a right confirmed by the international rules and principles, to share the usage of water from the Tigris and Euphrates Rivers with the upstream countries comprising of Turkey, Syria, and Iran. This paper suggests that all riparian countries of the Tigris and the Euphrates should abide by the rules of international law and recognize Iraq's historical water ratios of these rivers based on the principle of the acquired right under international law.
\end{abstract}

Keywords:

Legal Rights, Doctrinal Legal Research, International Law, International Water Resources, Tigris And Euphrates Rivers

\section{Introduction}

Water is the most essential natural resource for life and fundamental to all vital process of human activities. A study by the United Nations World Water Development Report (UNWWAP) in 2015 confirmed how water resources and services are essential to achieving 


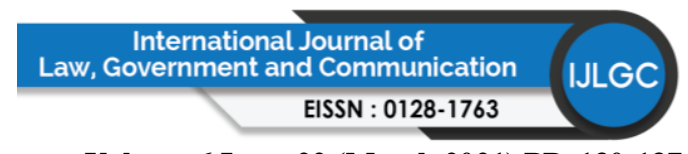

Volume 6 Issue 22 (March 2021) PP. 130-137

DOI 10.35631/IJLGC.6220012

global sustainability. Being a key factor for sustainable development, water supports not only for humans' health but also for food production and economic growth activities especially in sectors that are heavily water-dependent such as agriculture, fishing, energy, industry and health.

Alas, water, especially freshwater is a scant resource (Ramadan, 2015; Kirschner and Tiroch, 2012) as it makes up only a very small fraction of all water on the earth with about 2 to $3 \%$ although almost $70 \%$ of the earth's surface is covered with water. In a comprehensive study on global water crisis, Newton (2016:5) highlights the scarcity of fresh water which is confirmed by modern estimates of the amount of water available on earth comprising of $96.5 \%$ in the oceans, $2.5 \%$ in the form of lakes, rivers, streams and other freshwater resources and less than $1 \%$ in the form of saline (salt) water.

Shortage of water resources significantly leads to difficulty in sustaining natural ecosystems thus, limiting sustainable socioeconomic development (Wu et.al., 2016). The recent climate change, together with the effects of localized human activity, such as the use of water for irrigation agriculture, may have significant effects on the status of the water resources especially in the arid or semi-arid areas (Ramadan, 2015) including the Middle East and North Africa (MENA) region. The MENA region can be considered as the most water-scarce region of the world with per capita freshwater supplies well below the water "poverty" line of 1,000 cubic meters per year (Devlin, 2014). This region is the home of more than $6 \%$ of world's population but it contains less than $2 \%$ of the world's renewable water supply, making it the world's driest region ${ }^{1}$ (Al-Otaibi, 2015; Al-Rimmawi, 2012).

The source of water in the Middle East region mainly depends on few rivers. The Tigris and Euphrates rivers are the two major source of water which frame an area that is historically known as Mesopotamia (land between two rivers). The Tigris and Euphrates rivers originate in the Taurus mountains of south-eastern Turkey flow southwards in parallel into the arid plains of Syria and Iraq before converging again and flowing into the Arabian Gulf (also known as Persian Gulf by some countries) in the lowlands in an area known as the Shatt al-Arab (National Geographic Society, 2019). The Tigris-Euphrates river basin covers a large area which shared between the riparian ${ }^{2}$ countries of Turkey, Syria, Iraq and $\operatorname{Iran}^{3}$ (McClimans, 2017; Zentner, 2012:144).

The aim of this paper is to examine Iraq's rights, being the downstream country, towards the use of Tigris and Euphrates Rivers and the extent to which international water resources are protected under international law. The principles provided by the existing international conventions and protocols in this area are examined by adopting a doctrinal legal research approach which having great significance in assisting legal scholars to clearly understand the substantive law relevant to their research through the analysis of legal rules, court judgments and statutes (Mohamed, 2016:5194).

\footnotetext{
In some countries, a per capita share of available water has even dropped to 170 cubic meters per year.

"Riparian" simply means that they are situated on the banks of the aforementioned rivers.

Kuwait and Saudi Arabia have also benefit from the rivers at the area of Shatt al-Arab when the rivers flow into the Arabian Gulf (also known as Persian Gulf).

Copyright $\odot$ GLOBAL ACADEMIC EXCELLENCE (M) SDN BHD - All rights reserved
} 


\section{The Usage of the Tigris and Euphrates Rivers}

DOI 10.35631/IJLGC.6220012

The Tigris and Euphrates rivers irrigate and become a source of water supply in several countries including Turkey, Syria, Iraq, Iran and Kuwait (Tamimi, 1999:106) (see Figure 1). The rivers have been used by the civilizations of the region for thousands of years and were relatively unregulated (McClimans, 2017). During ancient Mesopotamia (today, Iraq), several civilizations were formed on the banks of these two rivers. Some of the major Mesopotamian civilizations (in Iraq) include the Sumerian, Assyrian, Akkadian, and Babylonian civilizations. Evidence demonstrates widespread use of technology, literature, legal codes, philosophy, religion and architecture in these societies (History.com Editors, 2019). The first legal rule regulated on the use of water in Mesopotamia were codified in the Code of Hammurabi in 1790 BC, which was considered as one of the oldest legal written laws (Ameen, 2007:8).

\section{Figure 1: Tigris-Euphrates-River-System}

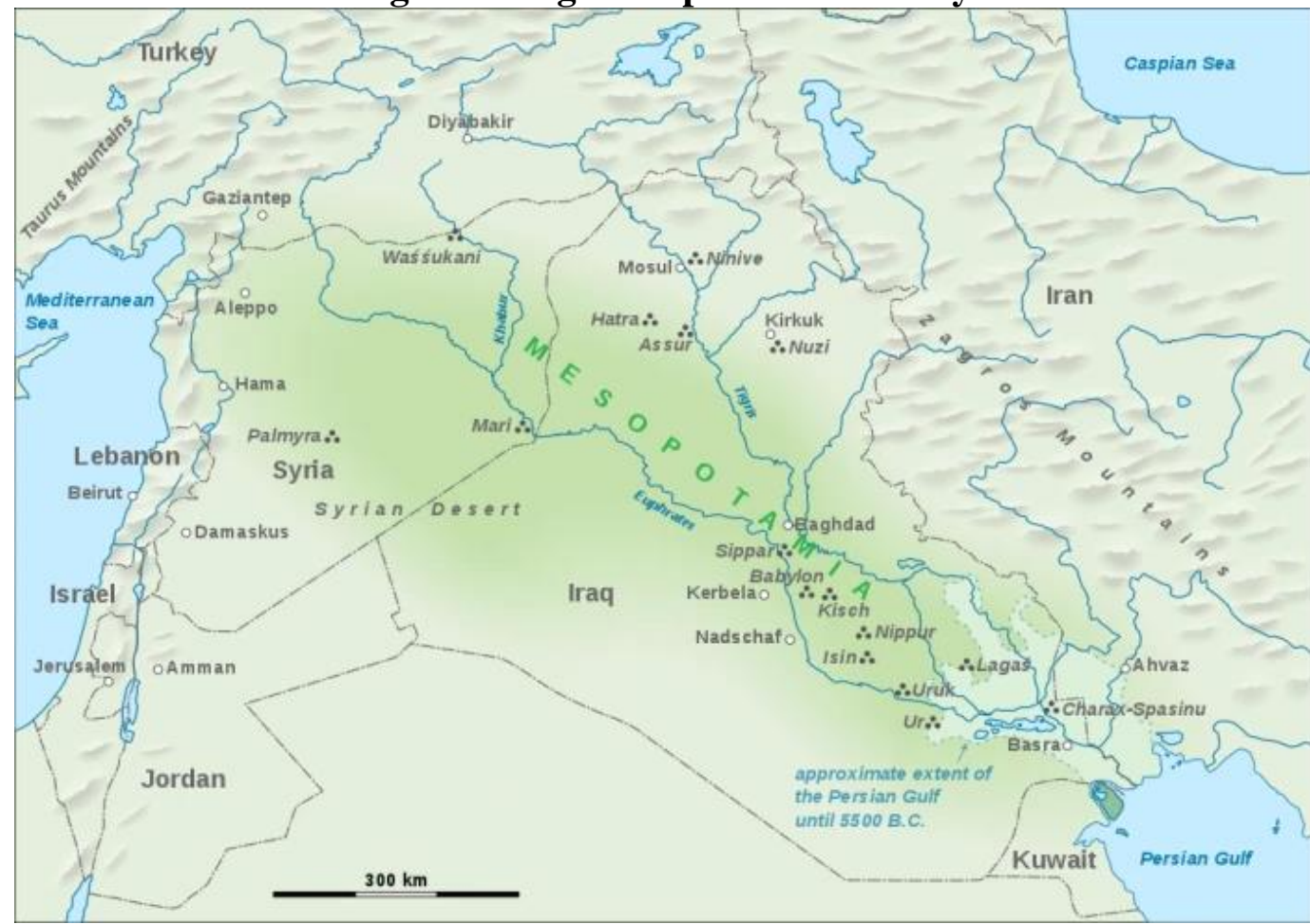

Source: Goran tek-en/Wikimedia Commons/CC BY-SA $4.0<\mathrm{https}$ //www.history.com/topics/ancient-middleeast/mesopotamia>

After the liberation of Iraq in the seventh century (AD) by the Islamic armies, the country was attached to the Islamic state. The Arabs and the Muslims maintained the existing irrigation projects, slit new channels of the rivers and built the city of Kufa on the banks of the Euphrates (Al-Hayali, 1995:21). They also slit a channel to convert the water of the Little Zab River during floods and set up a special office known as 'Water Office' to specifically dealt with water issues (Al-Zubaidi, 2008:35). During the Abbasid era, the use of the Tigris-Euphrates rivers had reached into a great level of development and extended into four streams of Essa, Sarsar, Al-Malik and Kothie rivers (Sadiq, 1976:222).

In $1638 \mathrm{AD}$, the Ottomans took control of Iraq and they used the Euphrates for navigational purposes to transfer the supplies and equipment (Al-Khairu, 1976:95.) During the British occupation of Iraq, the military authorities embarked on repairing and maintaining the existing streams to use them and formed the first Directorate for irrigation in 1918 by the British Copyright $\odot$ GLOBAL ACADEMIC EXCELLENCE (M) SDN BHD - All rights reserved 


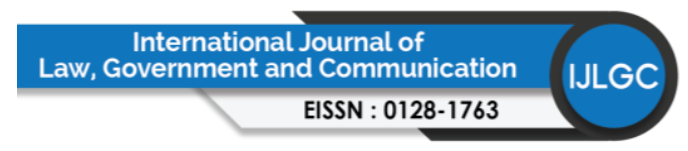

Volume 6 Issue 22 (March 2021) PP. 130-137

DOI 10.35631/IJLGC.6220012

engineers (Al-Zubaidi, 2008:40). When Iraq obtained independence in 1921, the government re-organized the methods of using water and created new irrigation channels, built up dams and water reservoirs on the Tigris and Euphrates, Zab and Diyala rivers.

In recent decades, the governments of the countries through which the rivers flow have increasingly used the rivers for hydroelectric power and flood control in addition to irrigation. Since 1960s, Turkey, Syria and Iraq began to scale up their use of these rivers and built dams to protect against floods and provide for droughts. The development of dams has exacerbated the loss of water in the region and led to water disputes among the countries (McClimans, 2017; The Open University, 2016).

Turkey, as the upstream country, claims the right to control the water that originates within its border. On the other hand, Iraq claims historical rights to the rivers as its people have depended on them for thousands of years, in what was Mesopotamia, using them for large-scale irrigation. Syria claims both ownership rights and historical user rights. Both Syria and Iraq claimed the Turkish government restricted the flow of the Tigris and Euphrates by building a large scale of dams in order to meet its own domestic needs (McClimans, 2017). The limited water resources of the region have led to international disputes over water supplies and, at times, threats of war (The Open University, 2016).

\section{The Acquired Rights of International Water Resources Under International Law}

According to Encyclopedic Dictionary of International Law, the term acquired right is used to connote private rights, acquired either by national or by aliens, under the existing law of a given State which, according to international law, do not cease on a change of sovereignty, and in the event of State succession, must be respected by the successor State. By virtue of the right to permanent sovereignty over natural wealth and resources, the successor State may, for reasons of public utility, security, or the national interest, cancel such rights provided that prompt, adequate, and effective compensation is paid to the beneficiary (Grant and Barker, 2009:5).

The concept of acquired right under international law was adopted from historical practice of using international watercourse among riparian countries. The use and application of international law has led the concept of acquired rights into a stable and binding customary rule. Under this concept, countries are obliged to respect each other's rights concerning the usage of international watercourses (Ibrahim, 1995:468). Even during the ancient civilization developed along the great rivers such as the Hwang Ho, Tigris and Euphrates, Nile, Indus, Ganges and Tiber, those ages people appreciated the need to have a body of rules governing the use made of waters and at the same time recognizing two principles - the sovereignty of the State on the territory on which water resources of interest to other States were to be found, and the principle of international cooperation and solidarity - as a basis on which to organize the joint use of the resource (Caponera, 1980:6).

The importance of the concept of acquired rights established by the international customary rule and its role in achieving justice and international peace had been recognized and adopted into international conventions concerning the issue of international watercourse. The concept had been stipulated into several treaties including the followings:

- The Convention and Statute on the International Régime of Maritime Ports 1923 (Geneva Agreement 1923) under the auspices of the League of Nations: Article 2 stated "consideration must be given to former users". 


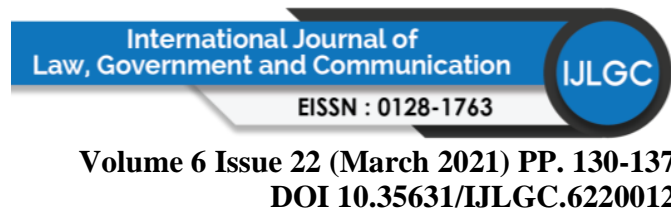

- Anglo-Egyptian Treat 1929 (agreement between Britain and Egypt) to share the water of the Nile between Egypt and Sudan, which stated the rule of the acquired right for both countries in the Nile water (Tamimi, 1999:153).

- Agreement between the United Arab Republic and the Republic of Sudan for the Full Utilization of the Nile Waters 1959, where the countries agreed on the acquired rights of Egypt and Sudan and on the need to preserve the historical shares from the water of this river (Ketchell, 2018).

- The Helsinki Rules on the Uses of the Waters of International Rivers 1966 is the most important rules which adopts the concept of acquired right. Article 5 of this Rules states on the fair and reasonable standards to use the water of the international river, including the provision in paragraph (4) which states that "the past utilization of the waters of the basin, including in particular existing utilization." This provision is considered as one of the criteria for determining quotas and utilizing the water of the International River Basin" (Amer, 2004).

In addition, the International Jury ${ }^{4}$ (formed under United Nations Department of Economic and Social Affairs), has adopted the principle of acquired rights and stated in its rulings, such as in the dispute between Iran and Afghanistan on Helmand River in 1951 where the jury suggested the countries to respect the concept of acquired rights by recommending that Iran's share of the Helmand waters amount to twenty-two cubic meters per second (Ibrahim, 1995). In a dispute between Ecuador and Peru in 1945 on Jarunela River, the International Jury made a suggestion requiring Peru to respect the historical right and the old flow of the river between the two countries (Sadiq, 1976:153). This shows how the concept of acquired right is deemed as a persuasive customary rule recognized under the principle of international law and thus has to be respected by all riparian countries sharing international watercourses.

In terms of the dispute involving the Tigris and the Euphrates, the Treaty of Lausanne 19221923 and the agreement entered into between Turkey and the Allied States, it is important to point out that Article 109 of the Treaty deals with the concept of acquired right. This Article states that "In default of any provisions to the contrary, when as the result of the fixing of a new frontier the hydraulic system (canalisation, inundation, irrigation, drainage or similar matters) in a State is dependent on works executed within the territory of another State, or when use is made on the territory of a State, in virtue of pre-war usage, of water or hydraulic power, the source of which is on the territory of another State, an agreement shall be made between the States concerned to safeguard the interests and rights acquired by each of them."

Of all these international legal instruments, the most important would be the provision stipulated in the Statute of the International Court of Justice 1945. Article 38(1) of this Statute stated that:

The Court, whose function is to decide in accordance with international law such disputes as are submitted to it, shall apply:

a. international conventions, whether general or particular, establishing rules expressly recognized by the contesting states.

4 The Jury is formed by international experts of proven distinction in the water and communication sector from international organizations, initiatives, universities and Think Tanks. Accessed from: <https://www.un.org/ waterforlifedecade/jury_2013_edition.shtml>

Copyright (C) GLOBAL ACADEMIC EXCELLENCE (M) SDN BHD - All rights reserved 


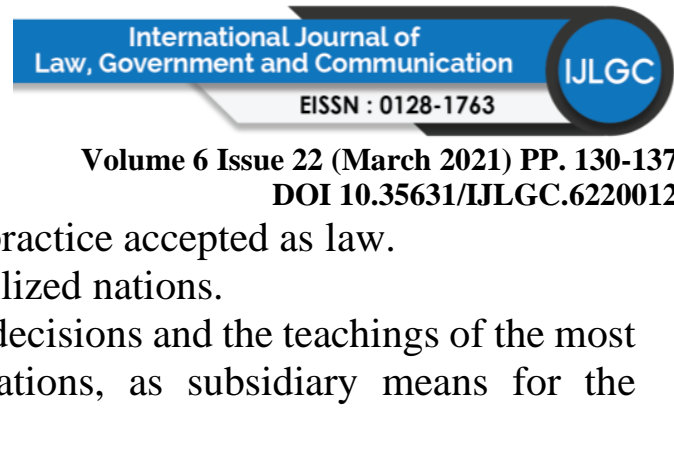

Article 38 of this Statute becomes the most commonly used procedure for creating rules of conduct between States where international water resources are concerned (Caponera, 1980:9). This provision indicates on respecting the previous traditions, customs or practice on the current and previous uses of the rivers among the sharing countries involved. In this context, based on the principle of acquired rights provided under the principle of international law, it is clear that Iraq is the oldest and the most frequent user of these two rivers in various sectors. Being a country in possession of the so-called acquired right, Iraq is considered having legal standing to bring and protect its rights in all international forums and to exchange official memos with the riparian countries on its rights as a downstream country against the upstream countries (Sadiq, 1976). Thus, in negotiating the use of these sharing rivers, other countries should respect and take into account the effects of the future development undertaken in their countries towards Iraq based on its acquired rights as recognised under international law.

\section{Conclusion}

Since ancient Mesopotamia, Iraq was among the countries which heavily depends on Tigris and Euphrates rivers for irrigation, water supply and other uses for the development and economic sustainability activities for the country. From the historical point of view, Iraq obtained the acquired rights which is recognized in modern times under international law to continuously having appropriate share in using the water from Tigris and Euphrates rivers. As such, any activities in the upstream countries that might affected the volume on and flow of the water to downstream countries should be taken into serious consideration by the countries involved. The acquired right confirmed by international rules and principles should be respected and complied with by all parties involved so that Iraq's rights to have appropriate ratio of water based on the previous practice will be acknowledged and recognized.

\section{Acknowledgements}

The authors would like to express their sincere gratitude to Universiti Utara Malaysia, 06010 UUM Sintok, Kedah Darul Aman, Malaysia for funding this study under Grant Insentif Pascasiswazah S/O Code: 15794 and also to College of Law and Political Science, Diyala University, Iraq.

\section{References}

Al-Hayali, Abdul Amir Abbas Abid. (1995). The Euphrates and the Arab water security. PhD Diss., Al-Mustansiriya University, College of Education.

Al-Khairu, Izzuldin. (1976). Euphrates and the international law. Baghdad: Al-Hurriya Press. Al-Otaibi, G. (2015). "By the numbers: Facts about water crisis in the Arab World." World Bank, 19 March 2015. Accessed at: <http://blogs.worldbank.org/arabvoices/numbersfacts about-water-crisis-arab-world> on 17 March 2017.

Al-Rimmawi, H. (2012). Middle East chronic water problems: Solution prospects, Energy and Environment Research, 2(1):28-34.

Al-Zubaidi, M.A.M.H. (2008). Iraqi water security: A study on the progress of negotiations in dividing the international waters. Baghdad: House of Cultural Affairs, 2008.

Ameen, M. (2007). The Code of Hammurabi. London: Dar Alwarrak Publishing Ltd.

Copyright (C) GLOBAL ACADEMIC EXCELLENCE (M) SDN BHD - All rights reserved 


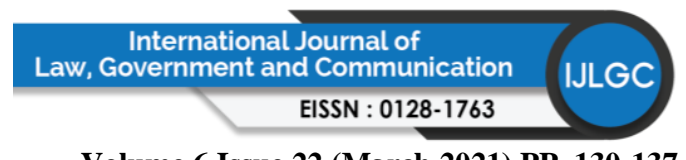

Volume 6 Issue 22 (March 2021) PP. 130-137

DOI 10.35631/IJLGC.6220012

Amer, S. (2004). United Nations Convention on the law of the non-navigational uses of international watercourses. Digital Ahram. Accessed at: <http://digital.ahram.org.eg/ articles.aspx?Serial=221228\&eid=475> on 13 March 2017.

Caponera, D.A. (1980). The law of international water resources. Rome: Food and Agriculture Organization of the United Nations. <http://www.fao.org/3/ak459E/ak459E.pdf>

Deutscher, G. (2007). Syntactic change in Akkadian: The evolution of sentential complementation. US: Oxford University Press.

Devlin, J. (2014). Is water scarcity dampening growth prospects in the Middle East and North Africa? Accessed at: $<$ https://www.brookings.edu/opinions/is-water-scarcity dampening-growth-prospects-in-the-middle-east-and-north-africa/>_on 17 March 2017.

Grant, J.P and Barker, J. C. (Eds.). (2009). Encyclopaedic dictionary of international law. 3rd edn. Oxford: Oxford University Press. Doi: 10.1093/acref/9780195389777.001.0001

History.com Editors. (2019). Mesopotamia. A\&E Television Networks, 30 September 2019. Accessed at: < https://www.history.com/topics/ancient-middle-east/mesopotamia> on 14 June 2020.

Ibrahim, A. (1995). Law of rivers and international watercourses. Cairo: Arab Renaissance Press.

Ketchell, M. (2018). Agreements that favour Egypt's rights to Nile waters are an anachronism. The Conversation, (4 November 2018). Accessed at: < https://theconversation.com/ agreements-that-favour-egypts-rights-to-nile-waters-are-an-anachronism-103353> on 10 January 2019.

Kirschner, A.J. and Tiroch, K. (2012). The waters of Euphrates and Tigris: An international law perspective. In: Max Planck Yearbook of United Nations Law Online. Vol. 16(1): 329-394. Doi: < https://doi.org/10.1163/18757413-90000021>

McClimans, M. (2017). Euphrates-Tigris water issues: An introduction. Ohio: PB Pressbooks.

Accessed at: < https://ohiostate.pressbooks.pub/etwr/front-matter/introduction/> on 13 April 2018.

Mohamed, K. (2016). Combining methods in legal research. Social Sciences, 11(21):51915198. Doi: 10.3923/sscience.2016.5191.5198

National Geographic Society. (2019). Tigris River. Encyclopedic Entry (26 April 2019), Accessed at: < https://www.nationalgeographic.org/encyclopedia/tigris-river/> on 27 July 2019.

Newton, D.E. (2016). The global water crisis: A reference handbook, California: ABC-CLIO, LLC.

Ramadan, E. Sustainable Water Resources Management in Arid Environment: The Case of Arabian Gulf. (2015) Int J Waste Resour 5(3):179. doi:10.4172/2252-5211.1000179

Sadiq, Ali Hussein. (1976). Iraq's acquired rights in the waters of the Euphrates. Master's thesis, Baghdad University, College of Law and Politics.

Tamimi, A. (1999). The Arab water: Challenge and response. Beirut: Centre of Arab Unity Studies.

The Open University. (2016). Global water resources. Accessed at: https://www.open.edu/ openlearn/science-maths-technology/science/environmental-science/global-waterresources/content-section-2.1\#fig008-002> on 17 March 2020.

UNWWAP (United Nations World Water Assessment Programme). (2015). The United Nations world water development report 2015: Water for a sustainable world. Paris, UNESCO. 
Volume 6 Issue 22 (March 2021) PP. 130-137 DOI 10.35631/IJLGC.6220012

Wu, D., Chen, F., Li, K., Xie, Y., Zhang, J. and Zhou, A. (2016). Effects of climate change and human activity on lake shrinkage in Gonghe Basin of northeastern Tibetan Plateau during the past 60 years. Journal of Arid Land, 8(4):479-491.

Zentner, M. (2012). Design and impact of water treaties: Managing climate change. Berlin: Springer-Verlag. 